\title{
Effectiveness of Surgical Prophylaxis Where the Antibiotic Resistance is High
}

\author{
Mehtap Aydın ${ }^{1}$ (D), Esra Nur Karadoğan ${ }^{\mathbf{1}}$ (iD, Ayten Kadanalı² (D) \\ 1 Department of Infectious Diseases and Clinical Microbiology, University of Health Sciences, Ümraniye Research and Training \\ Hospital, ístanbul, Turkey \\ 2 Department of Infectious Diseases and Clinical Microbiology, Biruni University School of Medicine, İstanbul, Turkey
}

\begin{abstract}
Objective: We aimed to investigate the risk factors for surgical site infections (SSI) and the effectiveness of prophylactic antibiotic use.

Methods: The demographic characteristics, comorbidities, and microbiological examinations of patients diagnosed with SSI who had a cholecystectomy, vaginal hysterectomy, knee prosthesis, hip prosthesis, and gastric surgery between January the 1st, 2014 and December the 31st, 2019 were retrospectively analysed. The diagnosis of healthcare-associated infections and SSI was based on the Centers for Disease Control and Prevention criteria.

Results: We detected Gram-negative bacteria in 30\% of knee prosthesis infections (60\% carbapenem-resistant), $60 \%$ of hip prosthesis infections (39\% carbapenem-resistant), $36 \%$ of vaginal hysterectomy (no carbapenem resistance), $50 \%$ of cholecystectomy (no carbapenem resistance), and $20 \%$ of gastric surgery (no carbapenem resistance). Staphylococci were the causative agents in 30\% of knee prosthesis infections (30\% methicillin-resistant) and $20 \%$ of hip prosthesis infections (38\% methicillin-resistant).

Conclusion: We detected multidrug resistance in microorganisms isolated from knee and hip replacement infections. Antibiotic resistance is a big problem, and antibiotic prophylaxis is insufficient to prevent SSI. Doctors should follow up with the patient who underwent surgery closely and take microbiological samples to select appropriate antibiotics when SSI develops.
\end{abstract}

Keywords: Surgical site infection, antibiotic, resistance

\section{INTRODUCTION}

S urgical site infections (SSI) are defined as infections that occur up to 30 days or one year after surgery in patients with implants, affecting the incision or deep tissue at the surgery site (1). They account for $20 \%$ of all healthcare-associated infections (HAI) in hospitalized patients. Patients with SSI are hospitalised additionally 7-11 days postoperatively. They have a two to 11 times higher risk of death compared with patients without SSI (2). Antimicrobial prophylaxis has a primary role in the prevention of SSI (3). Despite improvements in infection control and prevention, surgical site infections are still
Corresponding Author: Mehtap Aydın

E-mail:

mehtapaydin10@gmail.com

Received: November 08, 2020 Accepted: December 17, 2020 Published: December 31, 2020

\section{Suggested citation:}

Aydın M, Karadoğan NE, Kadanalı A. Effectiveness of Surgical Prophylaxis Where the Antibiotic Resistance is High Infect Dis Clin Microbiol 2020; 2: 128-132.

DOI: $10.36519 / \mathrm{idcm} .2020 .0027$ 
a problem associated with mortality and morbidity and seriously burden health resources (4). It was shown that one-year mortality for patients with SSI was $35.4-50 \%$, which was substantially higher than those without infection $(24.1-30 \%)(5,6)$. Patientrelated and procedure-related factors influence the risk of SSI. Although the causative pathogen usually originates from the patient's endogenous flora, it may also depend on the surgery type.

In the era of high antibiotic resistance, the effectiveness of antibiotic prophylaxis in SSI could be a problem. This study aimed to describe the risk factors for SSI after cholecystectomy, vaginal hysterectomy, knee replacement, hip replacement, and gastric surgery. We evaluated the effectiveness of the prophylactic antibiotic use for the responsible agents.

\section{METHOD}

Patients who underwent cholecystectomy, vaginal hysterectomy, knee prosthesis, hip prosthesis, and gastric surgery were diagnosed with SSI between January the 1st 2014, and December the 31st 2019 were enrolled in the study. The diagnosis of SSI was based on Centers for Disease Control and Prevention criteria (1). The demographic characteristics and microbiological investigations of patients were analysed retrospectively. The operations, which were followed for SSI surveillance by the infection control team, were examined. We obtained the data from the medical records of our hospital.

\section{RESULTS}

A total of 109 patients who underwent surgery and were diagnosed with SSI in Ümraniye Training and Research Hospital between January the 1st, 2014 and December the 31st, 2019 were included. Seventy-six $(70 \%)$ of those patients with SSI were women, and $33(30 \%)$ were male. The mean age of the patients who underwent knee and hip prosthesis surgery was 62 and 68, those who had vaginal hysterectomy and cholecystectomy was 55, and those who had gastric surgery was 47. Diabetes mellitus (DM) was the most common underlying disease among patients with SSI. Six (67\%) of the patients with knee prosthesis, $22(35 \%)$ of the patients with the hip

\section{HIGHLIGHTS}

- The percent of Gram-negative infections is high among surgical site infections.

- Carbapenem resistance is about \% 60 .

- The high prevalence of antimicrobial resistance is a barrier to appropriate antibiotic prophylaxis in SSI.

prosthesis, three (14\%) of the patients with vaginal hysterectomy, two (20\%) with cholecystectomy and one with gastric surgery had DM. Five patients with the hip prosthesis, five with vaginal hysterectomy, and one with cholecystectomy had malignancy. The number of patients with underlying hypertension was four (40\%) for knee prosthesis, 20 (32\%) for hip prosthesis, three $(30 \%)$ for cholecystectomy and one $(20 \%)$ for gastric surgery (Table 1$)$.

All the patients received prophylactic antibiotics prior to the operation. The appropriateness of selected antibiotics for the type of SSI was 99\%, the appropriateness of the dose was $100 \%$, but the appropriateness of the duration was $40 \%$.

Among the SSI, the rate of Gram-negative bacteria was 30\% in knee prosthesis, $60 \%$ in hip prosthesis, $36 \%$ in vaginal hysterectomy, 50\% in cholecystectomy, and 20\% in gastric surgery. Carbapenem resistance among Gram-negative bacteria was detected in $60 \%$ of the knee and $39 \%$ of hip prosthesis infections. Staphylococci were determined as the causative agents in 30\% of knee prosthesis infections (30\% methicillinresistant) and $20 \%$ of hip prosthesis infections (38\% methicillin-resistant) (Table 2).

\section{DISCUSSION}

Risk factors for SSI can be due to patient-related and procedure-related characteristics. In our study, most of the patients with SSI were female (70\%). The type of operation varied the distribution of age and gender. DM and malignancy are known to be major risk factors for SSI (7-9). Similarly, we found that DM was an underlying risk factor for SSI in all five surgery types. DM was more common 
Table 1. Demographic characteristics and the risk factors for surgical site infections

\begin{tabular}{|c|c|c|c|c|c|}
\hline Characteristics & $\begin{array}{c}\text { Knee Prosthesis } \\
n=9(\%)\end{array}$ & Hip & Vaginal & $\begin{array}{c}\text { Cholecystectomy } \\
n=10(\%)\end{array}$ & $\begin{array}{c}\text { Gastric surgery } \\
n=5(\%)\end{array}$ \\
\hline Age (SD) & $62( \pm 3)$ & $68( \pm 19)$ & $55( \pm 12)$ & $55( \pm 18)$ & $47( \pm 16)$ \\
\hline \multicolumn{6}{|l|}{ Sex } \\
\hline Female & $8(89)$ & $38(60)$ & $22(100)$ & $6(60)$ & $2(40)$ \\
\hline Male & $1(11)$ & $25(40)$ & $0(0)$ & $4(40)$ & $3(60)$ \\
\hline \multicolumn{6}{|l|}{ Comorbidity } \\
\hline DM & $6(67)$ & $22(35)$ & $3(14)$ & $2(20)$ & $1(20)$ \\
\hline Malignancy & $0(0)$ & $5(8)$ & $5(23)$ & $1(10)$ & $0(0)$ \\
\hline Hypertension & $4(44)$ & $20(32)$ & $0(0)$ & $3(30)$ & $1(20)$ \\
\hline
\end{tabular}

Table 2. Surgical site infections and pathogen distribution

\begin{tabular}{|c|c|c|c|c|c|}
\hline Microorganisms & $\begin{array}{c}\text { Knee Prosthesis } \\
\text { N:9 }\end{array}$ & $\begin{array}{l}\text { Hip Prosthesis } \\
\text { N:63 }\end{array}$ & $\begin{array}{c}\text { Vaginal } \\
\text { hysterectomy } \\
\mathrm{N}: 22\end{array}$ & $\begin{array}{c}\text { Gastric surgery } \\
\qquad \mathrm{N}: 5\end{array}$ & $\begin{array}{c}\text { Cholecystectomy } \\
\mathrm{N}: 10\end{array}$ \\
\hline A. baumanni & $1(11)$ & $7(11)$ & $1(5)$ & - & - \\
\hline K. pneumoniae & $2(22)$ & $9(14)$ & - & - & $2(20)$ \\
\hline E. coli & - & $6(10)$ & $3(14)$ & - & $1(10)$ \\
\hline P. aeruginosa & - & $9(14)$ & $3(14)$ & - & $1(10)$ \\
\hline P. vulgaris & - & $1(2)$ & - & - & - \\
\hline Enterobacter spp. & - & $5(8)$ & $1(5)$ & - & $1(10)$ \\
\hline M. morgagnii & - & $1(2)$ & - & - & - \\
\hline Citrobacter spp. & - & - & - & $1(20)$ & - \\
\hline Streptococcus spp. & - & - & - & $3(60)$ & - \\
\hline Enterococus spp. & - & $6(10)$ & $2(9)$ & - & $1(10)$ \\
\hline S. aureus & $2(22)$ & $11(17)$ & $3(14)$ & - & - \\
\hline CNS & $1(11)$ & $2(3)$ & - & - & - \\
\hline C. albicans & - & - & - & - & $1(10)$ \\
\hline No pathogen & $3(33)$ & $6(10)$ & $9(41)$ & $1(20)$ & $3(30)$ \\
\hline
\end{tabular}

CNS: Coagulase negative staphylococcus

in patients with infections of knee prosthesis (67\%), and it was followed by the hip prosthesis, cholecystectomy $(20 \%)$, gastric surgery $(20 \%)$, and vaginal hysterectomy (14\%). Malignancy was an underlying disease in patients who developed SSI after hip replacement, vaginal hysterectomy, and cholecystectomy.
In many SSIs, the responsible pathogens originate from the patient's endogenous flora. The causative pathogens depend on the type of surgery; Staphylococcus aureus, coagulase-negative staphylococci, Enterococcus spp. and Escherichia coli are the most commonly isolated organisms from SSI (3). Kaya et al. reported that the most common 
microorganism isolated from SSI was S.aureus (20\%) and E.coli (17.8\%), K.pneumonia (8.9\%), P. aeruginosa (8.9\%) respectively (10).

There is a large difference between countries in Europe for the methicillin-resistant S.aureus (MRSA) rates. The mean rate of MRSA detected in HAI was $16.4 \%$ in European countries (11).

According to the annual reports of the National Antimicrobial Resistance Surveillance System between 2014 and 2019, the methicillin resistance among S.aureus isolates was 51.85\%, 35\%, 23.6\%, and $40.82 \%$, respectively (12). In the studies from our country, the rate of methicillin resistance in S.aureus isolated from SSI was 25\% (7); we found $30 \%$ for knee and 38\% for hip prosthesis infections. Also, we detected a substantial percentage of Gram-negative bacteria in knee (30\%) and hip (60\%) prosthesis infections.

In our study, the rate of the Gram-negative bacteria responsible for the infections of the cholecystectomy was 50\%, 36\% for vaginal hysterectomy, 60\% for hip prosthesis, 30\% for knee prosthesis, and $10 \%$ for gastric surgery. According to recommendations of the recent guidelines, cefazolin or ceftriaxone, or ampicillin-sulbactam was used for prophylaxis of SSI (3). However, carbapenem resistance among Gram-negative bacteria was detected in $60 \%$ of the knee and $39 \%$ of the hip prosthesis infections.

The role of antimicrobial prophylaxis in reducing the risk of SSI is essential. It is estimated that up to $60 \%$ of SSIs are preventable using evidencebased guidelines (13). The problem of antimicrobial resistance is increasing in our country and worldwide $(14,15)$. The MDR bacteria were found to be responsible for the SSI (16). In our study, microorganisms isolated from knee and hip prosthesis infections are resistant to broadspectrum antibiotics. Antibiotic prophylaxis was insufficient in preventing surgical site infections in some patients. The rate of inappropriate antibiotic use was $40 \%$ for surgical prophylaxis. The patients received antibiotics longer than advised, contributing to antibiotic resistance.

\section{CONCLUSIONS}

Patients with underlying diseases such as DM or malignancy and those who have undergone surgery should be closely followed up, and if SSI develops, microbiological sampling should be implemented for appropriate antibiotic selection. Local surveillance of antimicrobial resistance is critical for the selection of appropriate antibiotics in SSI.
Informed Consent: Written consent was obtained from the patients.

Ethical Approval: Ümraniye Research and Training Hospital of Health Sciences University Ethical Committee for Research Studies approved the study with the decision number of Ref.No. B.10.1TKH.4.34.H.GP.0.01.

Peer-review: Externally peer-reviewed

Author Contributions: Concept - A.K., M.A.; Design - M.A.; Supervision - M.A.; Fundings - M.A., A.K.; Materials - E.N.K.;
Data Collection and/or Processing - E.N.K.; Analysis and/or Interpretation - M.A.; Literature Review - M.A.; Writer - M.A.; Critical Reviews - M.A., A.K.

Conflict of Interest: The authors have no conflict of interest to declare.

Financial Disclosure: The authors declared that this study has received no financial support. 


\section{REFERENCES}

1 Centers for Disease Control and Prevention. CDC/NHSN surveillance definitions for specific types of infections. Atlanta, GA: CDC; 2017.

2 Anderson DJ, Podgorny K, Berríos-Torres SI, Bratzler DW, Dellinger EP, Greene L, et al. Strategies to prevent surgical site infections in acute care hospitals: 2014 update. Infect Control Hosp Epidemiol 2014; 35: 605-27.

3 Bratzler DW, Dellinger EP, Olsen KM, Perl TM, Auwaerter PG Bolon MK, et al. Clinical practice guidelines for antimicrobial prophylaxis in surgery. Surg Infect (Larchmt) 2013; 14: 73-156.

4 Perencevich EN, Sands KE, Cosgrove SE, Guadagnoli E, Meara E, Platt R. Health and economic impact of surgical site infections diagnosed after hospital discharge. Emerg Infect Dis 2003; 9: 196-203.

5 Partanen J, Syrjälä H, Vähänikkilä H, Jalovaara P. Impact of deep infection after hip fracture surgery on function and mor tality. J Hosp Infect 2006; 62: 44-9.

6 Edwards C, Counsell A, Boulton C, Moran CG. Early infection after hip fracture surgery: risk factors, costs and outcome. J Bone Joint Surg Br 2008; 90: 770-7.

7 Telli Dizman G, Aktaş F, Sökülmez Yıldırım S, Uğraş Dikmen A. Investigation of incidence and risk Factors of surgical site infections after cardiothoracic surgery. Klimik Journal 2019; 32: 182-9.

8 Kohli M, Yuan L, Escobar M, David T, Gillis G, Comm B, et al. A risk index for sternal surgical wound infection after cardiovascular surgery. Infect Control Hosp Epidemiol 2003; 24: 17-25.

9 Liu X, Dong Z, Li Jun, Feng Y, Cao G, Song X, et al. Factors affecting the incidence of Surgical site infection after geriatric hip fracture surgery: a retrospective multicenter study. J Orthop Surg Res 2019; 14: 382.
10 Kaya E, Yetim I, Dervisoglu A, Sünbül M, Bek Y. Risk Factors and effect of a one-year surveillance program on surgical site infection at a university hospital in Turkey. Surg Infect (Larchmt) 2006; 7: 519-26.

11 EARS. Surveillance of antimicrobial resistance in Europe 2018. Stockholm: European Centre for Disease Prevention and Control (ECDC) 2019

12 Republic of Turkey Ministry of Health, Department of Microbiology Reference Laboratory. Ulusal Antimikrobiyal Direnç Sürveyans Sistemi 2016 Ylllık Raporu (National Antimicrobial Resistance Surveillance System 2016 Annual Report). Available from: URL: https://hsgm.saglik.gov.tr/depo/birimler/Mikrobiyoloji Referans Laboratuvarlari ve Biyolojik Urunler DB/uamdss/yillik raporlar/UAMDSS 2016 Rapor.pdf?type=file

13 Meeks DW, Lally KP, Carrick MM, Lew DF, Thomas EJ, Doyle PD, et al. Compliance with guidelines to prevent surgical site infections: as simple as 1-2-3? Am J Surg 2011; 201: 76-83.

14 Aydın M, Ergönül Ö, Azap A, Bilgin H, Aydın G, Çavuş SA, et al. Rapid emergence of colistin resistance and its impact on fatality among healthcare-associated infections. J Hosp Infect 2018; 98: 260-3

15 Centers for Disease Control and Prevention. About antibiotic resistance. 2020 March 13. Available from: URL: https://www. cdc.gov/drugresistance/about.html

16 Bilgiç Ç, Keske Ş, Sobutay E, Can U, Zenger S, Gürbüz B, et al. Surgical site infections after pancreaticoduodenectomy: Preoperative biliary system interventions and antimicrobial prophylaxis. Int J Infect Dis 2020; 95: 148-52. 